\title{
Thidiazuron effects on shoot growth, return bloom, fruit set and nutrition of apples ${ }^{(1)}$
}

\author{
Cassandro Vidal Talamini do Amarante ${ }^{(2)}$, Paulo Roberto Ernani( ${ }^{(3)}$, \\ Luiz Eduardo Bassay Blum ${ }^{(2)}$ and Clarice Aparecida Megguer ${ }^{(2)}$
}

\begin{abstract}
Apple (Malus domestica Borkh.) trees, cultivars Gala and Fuji, were sprayed at full bloom with thidiazuron (TDZ) at doses of $0,5,10$, or $20 \mathrm{~g} \mathrm{ha}^{-1}$ of a.i. in order to evaluate its effects on plant growth and development, return bloom, fruit set, nutrition, and fruit yield. Fruit set increased with TDZ dose in 'Gala' but not in 'Fuji'. TDZ did not affect fruit yield in any cultivar. In 'Gala', the return bloom was reduced in about $50 \%$ at TDZ doses of 10 or $20 \mathrm{~g} \mathrm{ha}^{-1}$. TDZ increased shoot growth in both cultivars. In leaves, TDZ decreased the concentration of Ca and $\mathrm{Mg}$ in 'Gala' and of Mg in 'Fuji', but did not affect the chlorophyll content, leaf area, length, width, and dry mass per $\mathrm{cm}^{2}$ regardless of cultivar. In fruits, the effect of TDZ varied according to the portion evaluated. Highest doses of TDZ decreased the concentration of $\mathrm{Ca}$ and $\mathrm{K}$ in 'Gala' and of $\mathrm{K}$ in 'Fuji' in the entire fruits (flesh + skin); in the skin, highest doses of TDZ reduced the levels of $\mathrm{N}, \mathrm{Ca}$, and $\mathrm{Mg}$ in both cultivars, in addition to the level of $\mathrm{K}$ in 'Fuji'.

Index terms: Malus domestica, cytokinin, phenylurea, calcium, fruit yield, pollination, plant development.
\end{abstract}

Efeito do thidiazuron no crescimento, no florescimento, na frutificação e na nutrição em macieiras

Resumo - Macieiras (Malus domestica Borkh.), cultivares Gala e Fuji, foram pulverizadas na plena floração com thidiazuron (TDZ) nas doses de $0,5,10$ e $20 \mathrm{~g} \mathrm{ha}^{-1}$ de ingrediente ativo com o objetivo de serem avaliadas quanto ao crescimento, florescimento, nutrição, frutificação e rendimento de frutos. A frutificação efetiva aumentou com a dose de TDZ na cultivar Gala, mas não na cultivar Fuji. Os tratamentos não afetaram o rendimento de frutos em nenhuma cultivar. Na cultivar Gala o florescimento no ano posterior ao da aplicação de TDZ foi reduzido em cerca de $50 \%$ nas doses de 10 e $20 \mathrm{~g} \mathrm{ha}^{-1}$. O TDZ promoveu aumento no crescimento dos ramos do ano em ambas as cultivares. Nas folhas, o aumento nas doses de TDZ reduziu os teores de Ca e Mg na cultivar Gala, e de Mg na cultivar Fuji mas não afetou o conteúdo de clorofila, área, comprimento, diâmetro e massa seca $\mathrm{cm}^{-2} \mathrm{da}$ folha, em ambas as cultivares. Em frutos inteiros (polpa + casca), o aumento nas doses de TDZ reduziu os teores de Ca e K na cultivar Gala, e os teores de K na cultivar Fuji. Na casca dos frutos, o aumento dos níveis de TDZ reduziu a concentração de N, Ca e Mg nas duas cultivares, além de K na cultivar Fuji.

Termos para indexação: Malus domestica, citocinina, difenil uréia, cálcio, rendimento de frutos, polinização, desenvolvimento das plantas.

\section{Introduction}

Improvement of fruit set and fruit growth are essential to high yields and consequently to the prof-

\footnotetext{
(1) Accepted for publication on May 3, 2002.

(2) Universidade do Estado de Santa Catarina (Udesc), Centro de Ciências Agroveterinárias (CAV), Caixa Postal 281, CEP 88502-970 Lages, SC. E-mail: amarante@cav.udesc.br, a2lbb@cav.udesc.br, a6cam@cav.udesc.br

(3) Udesc, CAV. CNPq fellow. E-mail: a2pre@cav.udesc.br
}

itability of apple growers. Fruit yield can be increased by improving pollination, controlling the leaf-to-fruit ratio (achieved by means of pruning and fruit thinning), and by adequate fertilization and irrigation practices. Recently, more attention has been given to the use of plant growth regulators in order to improve fruit set and fruit growth in temperate fruit trees (Elfving \& Cline, 1993; Greene, 1995; Famiani et al., 1999).

Cell division and elongation, which affect the final fruit size, are promoted by the growth substances 
auxin, cytokinin, and gibberellin (Taiz \& Zeiger, 1998). Two synthetic substituted phenylureas, CPPU [N(2-chloro-4-pyridyl)-N'-phenylurea] and thidiazuron (TDZ; N-phenyl-N'-1,2,3-thiadiazol-5-ylureia), show cytokinin-like activity in plant tissues (Mok et al., 1987) and strong fruit growth promoting effect. CPPU has been very effective in promoting kiwifruit, grape, and apple fruit growth (Iwahori et al., 1988; Schuck \& Petri, 1991; Reynolds et al., 1992; Greene, 1993; Antognozzi et al., 1997; Costa et al., 1997; Famiani et al., 1999). TDZ promotes apple, kiwifruit, grape, persimmon, and cucumber fruit growth (Reynolds et al., 1992; Schuck \& Petri, 1992; Yang et al., 1992; Cruz Castillos et al., 1993; Elfving \& Cline, 1993; Greene, 1995; Itai et al., 1995; Famiani et al., 1999).

In apple trees, TDZ sprayed near the full bloom reduced crop load and, therefore, promoted fruit growth (Elfving \& Cline, 1993; Greene, 1995). TDZ sprayed at both, higher doses or later after full bloom, had a more substantial thinning effect on apple trees, with the magnitude of the response being cultivar specific. Greene (1995) reported fruit weight increases greater than 30\% for 'McIntosh' and 'Empire' apples sprayed at full bloom with TDZ at doses of $50 \mathrm{mg} \mathrm{L}^{-1}$ and $15 \mathrm{mg} \mathrm{L}^{-1}$, respectively. This effect was reduced when the trees were sprayed 18-22 days after full bloom. For 'Gala' and 'Golden Delicious' apples sprayed at full bloom with $10 \mathrm{mg} \mathrm{L}^{-1}$ of TDZ, the increase on fruit weight was greater than $40 \%$ (Tagliari, 1997).

However, treatments with TDZ might reduce return bloom in apples, depending on product concentration, time of application, and cultivar (Elfving \& Cline, 1993; Greene, 1995). Elfving \& Cline (1993) reported substantial effects of TDZ, at doses of 65 and $125 \mathrm{mg} \mathrm{L}^{-1}$, on vegetative growth, flowering behavior, and on mineral content of leaves and fruits in 'Empire' apples. TDZ increased trunk enlargement (possibly as a result of reduced crop load) and reduced shoot growth. Leaves from trees treated with TDZ had higher $\mathrm{K}$ and lower $\mathrm{N}, \mathrm{Ca}$, and $\mathrm{Mg}$ contents. TDZ effects on fruit-flesh nutrient concentration were associated with higher content of $\mathrm{K}$ and slightly lower content of calcium. However, the authors did not assess the incidence of physiological disorders and postharvest quality of the fruit. Greene (1995) reported a small increase of bitter pit inci- dence at harvest when apple trees were sprayed 18 days after full bloom with $15 \mathrm{mg} \mathrm{L}^{-1}$ of TDZ but not when the trees were sprayed at full bloom. The author did not report substantial effects of TDZ on flesh firmness and soluble solids content of the fruits.

Besides affecting tree physiology and fruit growth, TDZ also influences other aspects of fruit quality such as fruit shape (Yang et al., 1992; Greene, 1995; Famiani et al., 1999), maturity (Reynolds et al., 1992; Greene, 1995; Itai et al., 1995; Antognozzi et al., 1997; Famiani et al., 1999) and ripening (Reynolds et al., 1992; Greene, 1995).

The published information shows that TDZ has a diversity of physiological effects on treated plants, which depends on product concentration, time of application, plant species and cultivar. This, in association with environmental conditions, might have substantial impacts on the plant physiological response to the product. TDZ has been used in Southern Brazil to improve fruit set and fruit growth in apples (Tagliari, 1997). However, more information is required to characterize the physiological effects of this product on apple trees cultivated in this region.

The objective of this work was to evaluate the effects of different doses of TDZ, sprayed at full bloom, on nutrition, vegetative growth, return bloom, fruit set, fruit growth and yield of apple bearing trees.

\section{Material and Methods}

The study was conducted in a commercial orchard in Lages, SC, Southern Brazil. Ten-year-old apple trees, cultivars Gala and Fuji, grafted on Marubakaido rootstock, were sprayed at full bloom, in 1999, with TDZ at doses of $0,5,10$, or $20 \mathrm{~g} \mathrm{ha}^{-1}$ of a.i., with a total spray volume of $1,000 \mathrm{~L} \mathrm{ha}^{-1}$. The trees were treated with a tractor-mounted airblast sprayer. Spray barriers, made of polyethylene mounted on wood poles, were used to prevent spray drift between experimental plots. The experiment followed a completely randomized block design with four replicates. Each experimental unity was composed by five rows of eight plants. Only four plants in the center of the middle row were assessed for vegetative and reproductive growth, fruit set, yield, and fruit and leaf nutritional status.

All blossom clusters (at the pink stage of flower development; stage $\mathrm{F}_{2}$ ) on two representative limbs per tree were counted in 1999 (the year when the trees were treated with TDZ) and in 2000. Return bloom was expressed in 
terms of percentage of blossom clusters $\mathrm{cm}^{-2}$ limb crosssectional area in 2000 in relation to 1999. At the end of October drop period, all persisting fruit on each tagged limb were counted. Fruit set was quantified in terms of number of persisting fruit per limb cross-sectional area (PLCA) and per blossom cluster (PBC).

Limb (at a predetermined location, on two representative limbs per tree) and trunk (30 cm above the soil surface) cross-sectional area and shoot growth (on six shoots per tree) were measured at bloom and in the following spring. Eight midshoot leaves from current-season shoots were collected per plant on 15 December 1999 and assessed for length, width, area (with a leaf area integrator LI-COR model LI-3050A), chlorophyll content (with a Minolta chlorophyll meter, model SPAD-502), and dry matter $\mathrm{cm}^{-2}$ (by weighting the material after drying it for 48 hours at $70^{\circ} \mathrm{C}$ ).

Ten midshoot leaves from the current-season shoot and ten fruits per plant were collected thirty days before the start of the commercial fruit harvesting and at commercial harvesting, respectively, and assessed for $\mathrm{N}, \mathrm{K}, \mathrm{Ca}$, and $\mathrm{Mg}$ content. The fruit mineral composition was assessed for the entire fruit (flesh + skin) and for the skin. The dry leaves and the fresh fruit samples were digested with a mixture of sulfuric acid and hydrogen peroxide, as described by Adler \& Wilcox (1985). Nitrogen was quantified by steam distillation using a semi-micro'Kjeldahl equipment, as described by Ernani et al. (1997). Calcium and $\mathrm{Mg}$ were determined with an inductive coupled plasma spectrophotometer (ICP), and K with a flame emission spectrophotometer.

All fruit on each tagged limb were harvested at commercial maturity and assessed for total weight, total number and average fruit weight.
The data were subjected to statistical analysis using SAS (SAS Institute, 1990). Percentage data were transformed to arc $\sin [(\mathrm{x}+5) / 100]^{1 / 2}$ before submitting to the ANOVA. The effect of TDZ dose on each attribute assessed was analyzed by orthogonal polynomial contrasts.

\section{Results and Discussion}

On 'Gala', a cultivar characterized by having low fruit set, TDZ sprayed at full bloom improved fruit set up to the highest dose used (Table 1). On the other hand, 'Fuji' is characterized by high fruit set and, therefore, requires excessive fruit thinning. In this cultivar, TDZ sprayed at full bloom did not increase fruit set. The untreated 'Fuji' trees had a number of fruit $\mathrm{cm}^{-2}$ of limb cross-sectional area similar to 'Gala' trees treated with TDZ at doses of 10-20 $\mathrm{g} \mathrm{ha}^{-1}$. The number of fruit per blossom cluster on untreated 'Fuji' trees was about twice that of 'Gala' trees treated with TDZ at doses of 10-20 $\mathrm{g} \mathrm{ha}^{-1}$.

Greene (1995) did not find TDZ effects, sprayed at full bloom, on fruit set of 'McIntosh' at doses of 10 or $50 \mathrm{mg} \mathrm{L}^{-1}$, and of 'Empire', at doses up to $15 \mathrm{mg} \mathrm{L}^{-1}$. However, when applied at both, higher doses or later after full bloom, TDZ might have a thinning effect depending on the apple cultivar (Elfving \& Cline, 1993; Greene, 1995).

Flowering at the start of the experiment was uniform among treatments, averaging 6.5 and 2.8 blossom clusters $\mathrm{cm}^{-2}$ of limb cross-sectional area on 'Gala' and 'Fuji', respectively. A polynomial orthogonal contrast analysis indicated a highly sig-

Table 1. Fruit set and return bloom (mean \pm SE) of apple trees, cultivars Gala and Fuji, sprayed with different doses of thidiazuron (TDZ).

\begin{tabular}{|c|c|c|c|c|c|c|}
\hline \multirow{2}{*}{$\begin{array}{l}\text { TDZ } \\
\left(\mathrm{g} \mathrm{ha}^{-1}\right)\end{array}$} & \multicolumn{3}{|c|}{ 'Gala' } & \multicolumn{3}{|c|}{ 'Fuji' } \\
\hline & $\begin{array}{l}\text { Number of fruit } \\
\text { PCLA }^{(1)}\end{array}$ & $\begin{array}{c}\text { Number of fruit } \\
\text { PBC }^{(2)}\end{array}$ & $\begin{array}{l}\text { Return bloom } \\
(\%)^{(3)}\end{array}$ & $\begin{array}{l}\text { Number of fruit } \\
\text { PCLA }\end{array}$ & $\begin{array}{c}\text { Number of fruit } \\
\text { PBC } \\
\end{array}$ & $\begin{array}{c}\text { Return bloom } \\
(\%)\end{array}$ \\
\hline 0 & $3.5 \pm 0.4$ & $0.6 \pm 0.1$ & $99.7 \pm 9.5$ & $5.7 \pm 0.5$ & $2.1 \pm 0.3$ & $66.1 \pm 13.6$ \\
\hline 5 & $3.4 \pm 0.3$ & $0.6 \pm 0.1$ & $115.8 \pm 18.9$ & $4.6 \pm 0.4$ & $1.7 \pm 0.1$ & $54.1 \pm 8.4$ \\
\hline 10 & $5.1 \pm 0.7$ & $0.7 \pm 0.1$ & $53.5 \pm 7.0$ & $3.8 \pm 0.5$ & $1.8 \pm 0.2$ & $90.5 \pm 19.2$ \\
\hline 20 & $6.0 \pm 0.6$ & $1.3 \pm 0.2$ & $50.3 \pm 11.5$ & $6.0 \pm 0.5$ & $2.1 \pm 0.2$ & $79.3 \pm 22.5$ \\
\hline Linear & $* * *$ & $* * *$ & $* * *$ & ns & ns & ns \\
\hline Quadratic & ns & $*$ & ns & $* * *$ & ns & ns \\
\hline
\end{tabular}

(1)PCLA: per square centimeter of limb cross-sectional area. ${ }^{(2)} \mathrm{PBC}$ : per blossom cluster. ${ }^{(3)}$ Calculated as percentage of blossom clusters cm ${ }^{-2}$ limb crosssectional area between 2000 and 1999 . ns Non-significant, by means of polynomial orthogonal contrasts. * and ***Significant for $5 \%$ and $0.1 \%$ of probability, respectively. 
nificant linear effect of TDZ in reducing return bloom in 'Gala' (Table 1). For this cultivar, the return bloom was reduced to half in trees treated with TDZ at doses of $10-20 \mathrm{~g} \mathrm{ha}^{-1}$ in comparison to untreated trees. In 'Fuji', flowering determined in the next spring (spring following TDZ treatment) was reduced in all treatments by $40 \%$, with no effect of TDZ in the return bloom.

Some authors have shown that return bloom in apples is affected by TDZ concentration, time of application and cultivar (Elfving \&Cline, 1993; Greene, 1995). Greene (1995) reported a reduced return bloom on 'McIntosh' and 'Double Red Delicious' apples treated with TDZ. In 'McIntosh', more substantial reduction of return bloom occurred with increases on product concentration and with late spraying. At dose of $10 \mathrm{mg} \mathrm{L}^{-1}$, TDZ sprayed at full bloom or 22 days after full bloom reduced return bloom in more than $30 \%$ and $70 \%$, respectively. At dose of $50 \mathrm{mg} \mathrm{L}^{-1}$ TDZ reduced return bloom more than $70 \%$ when sprayed at full bloom, and more than $90 \%$ when sprayed 22 days after full bloom. In 'Double Red Delicious', 5 and $10 \mathrm{mg} \mathrm{L}^{-1}$ of TDZ, sprayed at full bloom, reduced return bloom more than $60 \%$. However, return bloom was not affected on 'Empire' trees treated with 1,5 , or $15 \mathrm{mg} \mathrm{L}^{-1}$ of TDZ, either at full bloom or 18 days after full bloom (Greene, 1995). For this cultivar, concentrations as high as 62 and $125 \mathrm{mg} \mathrm{L}^{-1}$ did not affect return bloom (Elfving \& Cline, 1993). The reduced return bloom caused by TDZ in some cultivars might be a direct effect of the product on flower bud formation. Flowering was inhibited on 'Delicious' where there was no treatment effect on fruit set, but on 'McIntosh' there was a general trend to have more inhibition of flowering on trees that thinned the most (Greene, 1995). In this study, the reduced return bloom in 'Gala' treated with highest doses of TDZ may be the result of higher fruit set, which can cause depletion of reserves for the flower bud differentiation (Faust, 1989), and/or promotion of vegetative shoot growth, that can also affect flower bud differentiation. In 'Fuji', flowering determined in the following spring was substantially reduced in all treatments, and, therefore, TDZ did not affect return bloom. However, this also might reflect low effects of TDZ on flower bud differentiation in this cultivar.

TDZ had no effect on the increment of trunk crosssectional area, but reduced limb cross-sectional area in 'Gala' (linear effect) (Table 2). On both cultivars, TDZ increased shoot growth.

Since the experimental area had high presence of bees, and the weather conditions were favorable for the entomophilic pollination, yield was not affected by TDZ treatments in any cultivar (Table 3 ). Average fruit weight did not increase with increases on TDZ dose. This result disagrees with previous published studies, which show substantial increase on fruit size with increases on TDZ doses (Reynolds et al., 1992; Yang et al., 1992; Greene, 1995; Itai et al., 1995; Famiani et al., 1999). However, those studies were performed mainly by dipping the fruit in a solution of TDZ, or by spraying some trees or some limbs per tree with the product to the drip point. This might result in much higher doses of TDZ than those applied in our study, where the plants were treated with a tractor-

Table 2. Vegetative growth (increment in \%; mean \pm SE) of apple trees, cultivars Gala and Fuji, sprayed with different doses of thidiazuron (TDZ).

\begin{tabular}{|c|c|c|c|c|c|c|}
\hline \multirow{2}{*}{$\begin{array}{c}\text { TDZ } \\
\left(\mathrm{g} \mathrm{ha}^{-1}\right)\end{array}$} & \multicolumn{3}{|c|}{ 'Gala' } & \multicolumn{3}{|c|}{ 'Fuji' } \\
\hline & $\begin{array}{l}\text { Trunk cross } \\
\text { section area }\end{array}$ & $\begin{array}{l}\text { Limb cross } \\
\text { section area }\end{array}$ & Shoot growth & $\begin{array}{l}\text { Trunk cross } \\
\text { section area }\end{array}$ & $\begin{array}{l}\text { Limb cross } \\
\text { section area }\end{array}$ & Shoot growth \\
\hline 0 & $4.0 \pm 1.4$ & $7.8 \pm 2.7$ & $33.8 \pm 2.5$ & $4.5 \pm 1.0$ & $7.5 \pm 2.3$ & $48.6 \pm 2.2$ \\
\hline 5 & $4.2 \pm 1.4$ & $7.1 \pm 2.8$ & $35.9 \pm 2.5$ & $3.1 \pm 1.0$ & $8.6 \pm 2.8$ & $42.6 \pm 2.1$ \\
\hline 10 & $4.5 \pm 1.3$ & $6.4 \pm 3.0$ & $33.4 \pm 2.4$ & $5.8 \pm 1.0$ & $6.9 \pm 2.5$ & $50.3 \pm 1.5$ \\
\hline 20 & $1.8 \pm 0.8$ & $2.2 \pm 2.2$ & $40.8 \pm 2.9$ & $2.6 \pm 1.6$ & $7.2 \pm 1.5$ & $51.9 \pm 1.9$ \\
\hline Linear & ns & $* *$ & $*$ & ns & ns & $*$ \\
\hline
\end{tabular}


mounted airblast sprayer, as done commercially. This might have reduced the product effectiveness in promoting fruit growth. Reynolds et al. (1992) also emphasized the importance of field trials to determine the effective concentration of TDZ when the product is sprayed commercially in grapes to promote fruit growth.

TDZ affected the distribution of nutrients between leaves on both cultivars (Table 4). Treatment with $20 \mathrm{~g} \mathrm{ha}^{-1}$ of TDZ increased Ca content in the leaf by about $27 \%$, in 'Gala'. The concentration of $\mathrm{Ca}$ in the 'Fuji' leaves was about twice that of 'Gala' and it was not affected by TDZ. 'Fuji' and 'Gala' Mg contents on leaf increased by $12 \%$ and $17 \%$, respectively, by treating the trees with TDZ at $20 \mathrm{~g} \mathrm{ha}^{-1}$. Concomitantly, TDZ decreased the fruit content of $\mathrm{Ca}$ and $\mathrm{Mg}$, especially in the skin tissue (Table 5). Calcium content in the skin reduced $17-20 \%$ with 10 $20 \mathrm{~g} \mathrm{ha}^{-1}$ of TDZ in both cultivars. In 'Gala', the same doses of TDZ reduced $\mathrm{Mg}$ and $\mathrm{N}$ content in the skin by $14-19 \%$ and by $10 \%$, respectively. In 'Fuji', these treatments reduced $\mathrm{Mg}$ and $\mathrm{N}$ content in the skin by $23-26 \%$ and by $20 \%$, respectively. Except for $\mathrm{K}$ in the leaves of 'Fuji' and for Ca in the leaves of 'Gala', all the other nutrients are in the normal range for apples, regardless of cultivar and tissue.

The nutritional results obtained in the present study are, however, in contrast to those reported by Elfving \& Cline (1993) on 'McIntosh' apples. These authors reported decreases on $\mathrm{N}, \mathrm{Ca}$, and $\mathrm{Mg}$ and increases on $\mathrm{K}$ content in the leaves, and increases on $\mathrm{K}$ content in the fruit-flesh. According to them, the increase on $\mathrm{K}$ and the reduction on $\mathrm{N}$ in the leaves, likely resulting from reduced crop load on trees treated with TDZ, may have induced lower Ca and $\mathrm{Mg}$ contents in the leaf. Since the doses of TDZ sprayed at full bloom in the present study increased fruit set and shoot growth, nutritional results different from those reported by Elfving \& Cline (1993) are foreseen.

The data show that the intense promoting growth effect of TDZ on vegetative tissues (terminal buds

Table 3. Yield and average fruit weight (mean \pm SE) of apple trees, cultivars Gala and Fuji, sprayed with different doses of thidiazuron (TDZ).

\begin{tabular}{|c|c|c|c|c|c|c|}
\hline \multirow{2}{*}{$\begin{array}{c}\text { TDZ } \\
\left(\mathrm{g} \mathrm{ha}^{-1}\right)\end{array}$} & \multicolumn{3}{|c|}{ 'Gala' } & \multicolumn{3}{|c|}{ 'Fuji' } \\
\hline & $\begin{array}{l}\text { Fruit weight (g) } \\
\text { PCLA }^{(1)}\end{array}$ & $\begin{array}{c}\text { Number of fruit } \\
\text { PCLA }\end{array}$ & $\begin{array}{c}\text { Average fruit } \\
\text { weight }(\mathrm{g})\end{array}$ & $\begin{array}{c}\text { Fruit weight (g) } \\
\text { PCLA }\end{array}$ & $\begin{array}{c}\text { Number of fruit } \\
\text { PCLA }\end{array}$ & $\begin{array}{c}\text { Average fruit } \\
\text { weight }(\mathrm{g})\end{array}$ \\
\hline 0 & $0.25 \pm 0.03$ & $2.01 \pm 0.23$ & $126.14 \pm 5.74$ & $0.22 \pm 0.02$ & $1.57 \pm 0.14$ & $142.97 \pm 3.09$ \\
\hline 5 & $0.20 \pm 0.03$ & $1.80 \pm 0.23$ & $110.49 \pm 5.74$ & $0.20 \pm 0.02$ & $1.30 \pm 0.11$ & $156.87 \pm 0.81$ \\
\hline 10 & $0.23 \pm 0.02$ & $1.91 \pm 0.15$ & $122.35 \pm 3.63$ & $0.20 \pm 0.02$ & $1.31 \pm 0.12$ & $148.80 \pm 3.06$ \\
\hline 20 & $0.24 \pm 0.02$ & $2.08 \pm 0.15$ & $113.68 \pm 3.63$ & $0.23 \pm 0.03$ & $1.53 \pm 0.16$ & $147.13 \pm 5.37$ \\
\hline Linear & $\mathrm{ns}$ & $\mathrm{ns}$ & $\mathrm{ns}$ & ns & $\mathrm{ns}$ & $\mathrm{ns}$ \\
\hline Quadratic & ns & ns & $\mathrm{ns}$ & ns & $\mathrm{ns}$ & $*$ \\
\hline
\end{tabular}

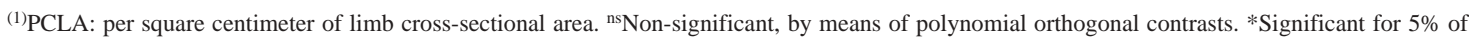
probability.

Table 4. Concentration of $\mathrm{Ca}, \mathrm{Mg}, \mathrm{K}$, and $\mathrm{N}$ in the leaves (mean $\pm \mathrm{SE} ; \mathrm{g} \mathrm{kg}^{-1}$ ) of apple trees, cultivars Gala and Fuji, sprayed with different doses of thidiazuron (TDZ).

\begin{tabular}{|c|c|c|c|c|c|c|c|c|}
\hline \multirow{2}{*}{$\begin{array}{c}\text { TDZ } \\
\left(\mathrm{g} \mathrm{ha}^{-1}\right)\end{array}$} & \multicolumn{4}{|c|}{ 'Gala' } & \multicolumn{4}{|c|}{ 'Fuji' } \\
\hline & $\mathrm{Ca}$ & $\mathrm{Mg}$ & $\mathrm{K}$ & $\mathrm{N}$ & $\mathrm{Ca}$ & $\mathrm{Mg}$ & $\mathrm{K}$ & $\mathrm{N}$ \\
\hline 0 & $7.0 \pm 0.3$ & $3.8 \pm 0.3$ & $11.3 \pm 1.2$ & $19.7 \pm 0.4$ & $14.6 \pm 1.2$ & $4.3 \pm 0.4$ & $7.7 \pm 0.5$ & $19.1 \pm 0.8$ \\
\hline 5 & $8.9 \pm 0.4$ & $3.8 \pm 0.2$ & $12.1 \pm 0.9$ & $19.3 \pm 0.7$ & $16.1 \pm 1.4$ & $4.4 \pm 0.1$ & $9.3 \pm 0.7$ & $18.3 \pm 0.6$ \\
\hline 10 & $7.9 \pm 0.6$ & $4.1 \pm 0.2$ & $11.0 \pm 0.8$ & $21.2 \pm 0.6$ & $13.8 \pm 1.5$ & $4.6 \pm 0.1$ & $7.2 \pm 0.7$ & $18.6 \pm 0.7$ \\
\hline 20 & $9.7 \pm 0.9$ & $4.6 \pm 0.1$ & $9.6 \pm 1.1$ & $19.9 \pm 0.6$ & $14.3 \pm 1.6$ & $4.9 \pm 0.3$ & $6.8 \pm 0.4$ & $19.6 \pm 0.3$ \\
\hline Linear & $*$ & $* *$ & ns & ns & $\mathrm{ns}$ & $*$ & ns & $\mathrm{ns}$ \\
\hline
\end{tabular}

${ }^{n}$ Non-significant, by means of polynomial orthogonal contrasts. * and **Significant for $5 \%$ and $1 \%$ of probability, respectively. 
Table 5. Concentration of $\mathrm{Ca}, \mathrm{Mg}, \mathrm{K}$, and $\mathrm{N}$ in the entire fruits (flesh + skin) and in the fruit skin (mean $\pm \mathrm{SE} ; \mathrm{mg} \mathrm{kg}^{-1}$ ) of apple trees, cultivars Gala and Fuji, sprayed with different doses of thidiazuron (TDZ).

\begin{tabular}{|c|c|c|c|c|c|c|c|c|}
\hline \multirow{2}{*}{$\begin{array}{c}\text { TDZ } \\
\left(\mathrm{g} \mathrm{ha}^{-1}\right)\end{array}$} & \multicolumn{4}{|c|}{ 'Gala' } & \multicolumn{4}{|c|}{ 'Fuji' } \\
\hline & $\mathrm{Ca}$ & $\mathrm{Mg}$ & $\mathrm{K}$ & $\mathrm{N}$ & $\mathrm{Ca}$ & $\mathrm{Mg}$ & $\mathrm{K}$ & $\mathrm{N}$ \\
\hline & \multicolumn{8}{|c|}{ Entire fruits } \\
\hline 0 & $78.4 \pm 5.0$ & $63.6 \pm 1.1$ & $945.9 \pm 32.5$ & $292.4 \pm 15.4$ & $63.2 \pm 7.2$ & $51.4 \pm 2.8$ & $922.8 \pm 37.1$ & $239.6 \pm 7.2$ \\
\hline 5 & $68.4 \pm 4.1$ & $60.1 \pm 1.5$ & $1,031.9 \pm 50.7$ & $248.0 \pm 15.4$ & $61.3 \pm 5.7$ & $54.4 \pm 4.0$ & $908.3 \pm 32.6$ & $228.6 \pm 12.1$ \\
\hline 10 & $61.2 \pm 3.8$ & $57.3 \pm 0.5$ & $869.8 \pm 59.7$ & $221.6 \pm 44.0$ & $53.6 \pm 6.0$ & $52.7 \pm 2.3$ & $859.4 \pm 46.9$ & $225.0 \pm 3.1$ \\
\hline 20 & $61.9 \pm 4.2$ & $58.9 \pm 4.3$ & $811.5 \pm 80.8$ & $272.6 \pm 25.9$ & $54.4 \pm 2.4$ & $52.5 \pm 3.0$ & $784.1 \pm 57.5$ & $242.1 \pm 9.3$ \\
\hline \multirow[t]{2}{*}{ Linear } & $*$ & $\mathrm{~ns}$ & $*$ & ns & $\mathrm{ns}$ & ns & $*$ & $\mathrm{~ns}$ \\
\hline & \multicolumn{8}{|c|}{ Fruit skin } \\
\hline 0 & $305.4 \pm 20.8$ & $312.3 \pm 14.6$ & $1,096.5 \pm 42.2$ & $828.5 \pm 36.0$ & $329.7 \pm 3.6$ & $306.7 \pm 13.7$ & $1,130.7 \pm 31.9$ & $929.1 \pm 37.5$ \\
\hline 5 & $257.3 \pm 23.5$ & $262.7 \pm 14.6$ & $1,181.0 \pm 106.3$ & $689.0 \pm 47.0$ & $284.3 \pm 22.9$ & $296.0 \pm 6.3$ & $1,217.0 \pm 28.6$ & $896.4 \pm 11.6$ \\
\hline 10 & $240.7 \pm 9.3$ & $253.0 \pm 6.1$ & $1,025.9 \pm 45.2$ & $743.9 \pm 20.8$ & $261.5 \pm 17.8$ & $227.6 \pm 13.5$ & $918.6 \pm 21.0$ & $727.2 \pm 32.8$ \\
\hline 20 & $253.5 \pm 10.8$ & $269.4 \pm 5.8$ & $1,000.7 \pm 68.5$ & $759.5 \pm 31.1$ & $272.2 \pm 11.7$ & $236.8 \pm 17.2$ & $903.1 \pm 88.4$ & $759.3 \pm 18.8$ \\
\hline Linear & $*$ & ns & $\mathrm{ns}$ & ns & $* *$ & $* * *$ & $* * *$ & $* * *$ \\
\hline Quadratic & $*$ & $* *$ & ns & $*$ & $*$ & ns & ns & $*$ \\
\hline
\end{tabular}

${ }^{n}$ Non-significant by means of polynomial orthogonal contrasts. *, ** and ***Significant for $5 \%, 1 \%$ and $0.1 \%$ of probability, respectively.

and growing leaves) might increase the accumulation of nutrients into these organs, especially calcium, in detriment of growing fruit.

\section{Conclusions}

1. Thidiazuron sprayed at full bloom might improve fruit set in cultivars with deficient pollination.

2. The product has negative side effects related to undue promotion of vegetative growth, which may contribute to reduce return bloom and mineral content in the fruit, especially of calcium.

\section{Acknowledgements}

To Yakult S.A. and Agrícola Fraiburgo S.A. for their support in conducting the field works; to the Associação Brasileira de Produtores de Maçã (ABPM) for the grant that partially supported this research.

\section{References}

ADLER, P. R.; WILCOX, G. E. Rapid perchloric acid digestion methods for analysis of major elements in plant tissue. Communications in Soil Science and Plant Analysis, Athens, v. 16, n. 11, p. 1153-1163, 1985.
ANTOGNOZZI, E. L.; FAMIANI, F.; FERRANTI, F.; FRENGUELLI, G.; PROIETTI, P.; TOMBESI, A. Effect of CPPU (cytokinin) treatments on fruit anatomical structure and quality in Actinidia deliciosa. Acta Horticulturae, Leuven, n. 444, p. 459-465, 1997.

COSTA, G.; SUCCI, F.; QUADRETTI, R.; MORIGI, M.; MISEROCCHI, O. Effects of CPPU and pollination on fruiting performance, fruit quality and storage life of kiwifruit (cv. Hayward). Acta Horticulturae, Leuven, n. 444, p. 467-472, 1997.

CRUZ CASTILLOS, J. C.; WOOLLEY, D. J.; LAWES, G. S. The effects of seeds and the application of a growth regulator mixture, on fruit growth in 'Hayward' kiwifruit. Acta Horticulturae, Leuven, n. 329, p. 128-130, 1993.

ELFVING, D. C.; CLINE, R. A. Cytokinin and ethephon affects crop load, shoot growth, and nutrient concentration of 'Empire' apple trees. HortScience, Alexandria, v. 28, n. 10, p. 1011-1014, 1993.

ERNANI, P. R.; DIAS, J.; VANZ, L. Application of nitrogen to the soil after fruit harvest has not increased apple yield. Revista Brasileira de Fruticultura, Cruz das Almas, v. 19, n. 1, p. 33-37, 1997.

FAMIANI, F.; BATTISTELLI, A.; MOSCATELLO, S.; BOCO, M.; ANTOGNOZZI, E. Thidiazuron affects growth, ripening and quality of Actinidia deliciosa. Journal of Horticultural Science and Biotechnology, Kent, v. 74, n. 3, p. 375-380, 1999. 
FAUST, M. Physiology of temperate zone fruit trees. New York: J. Wiley, 1989. 338 p.

GREENE, D. W. A comparison of the effects of several cytokinins on apple fruit set and fruit quality. Acta Horticulturae, Leuven, n. 329, p. 144-146, 1993.

GREENE, D. W. Thidiazuron effects on fruit set, fruit quality, and return bloom of apples. HortScience, Alexandria, v. 30, n. 6, p. 1238-1240, 1995.

ITAI, A.; TANABE, K.; TAMURA, F.; SUSAKI, S.; YONEMORI, K.; SUGIURA, A. Synthetic cytokinins control persimmon fruit shape, size and quality. Journal of Horticultural Science, Kent, v. 70, n. 6, p. 867-873, 1995.

IWAHORI, S.; TOMINAGA, S.; YAMASAKI, T. Stimulation of fruit growth of kiwifruit, Actinidia chinensis Planch., by N-(2-chloro-4-pyridyl)-N'-phenylurea, a diphenylurea derivative cytokinin. Scientia Horticulturae, Amsterdam, v. 35 , n. 1/2, p. 109-115, 1988.

MOK, M. C.; MOK, D. W. S.; TURNER, J. E.; MUJER, C. V. Biological and biochemical effects of cytokinin-active phenylureia derivatives in tissue culture systems. HortScience, Alexandria, v. 22, n. 6, p. 1194-1197, 1987.

REYNOLDS, A. G.; WARDLE, D. A.; ZUROWSKI, C.; LOONEY, N. E. Phenylureas CPPU and thidiazuron affects yield components, fruit composition, and storage potential of four seedless grape selections. Journal of the American Society for Horticultural Science, Alexandria, v. 117, n. 1, p. 85-89, 1992.

SAS INSTITUTE (Cary, Estados Unidos). Doing more with SAS/ASSIST software: version 6. Cary, 1990. 789 p.

SCHUCK, E.; PETRI, J. L. Efeitos do CPPU (citocinina) no crescimento e peso de frutos de quivi (Actinidia deliciosa). Revista Brasileira de Fruticultura, Cruz das Almas, v. 13, n. 1, p. 77-82, 1991.

SCHUCK, E.; PETRI, J. L. Efeitos do thidiazuron no peso médio dos frutos de quivi. Revista Brasileira de Fruticultura, Cruz das Almas, v. 14, n. 2, p. 185-188, 1992.

TAGLIARI, P. S. Nova tecnologia melhora rendimento e qualidade da maçã. Revista Agropecuária Catarinense, Florianópolis, v. 10, n. 4, p. 26-28, 1997.

TAIZ, L.; ZEIGER, E. Plant physiology. 2. ed. Sunderland: Sinauer Associates, 1998. 793 p.

YANG, Y. Z.; LIN, D. C.; GUO, Z. Y. Promotion of fruit development in cucumber (Cucumis sativus) by thidiazuron. Scientia Horticulturae, Amsterdam, v. 50, n. 1/2, p. 47-51, 1992. 